\title{
AL-IQTISHADIYAH
}

Jurnal Ekonomi Syariah dan Hukum Ekonomi Syariah

E-ISSN: 2621-0274; P-ISSN: 2442-2282

Volume 7, Nomor 2, Desember 2021

\section{Fenomena Endorsement Terhadap Penjualan Suatu Produk Ditinjau dari Etika Bisnis Islam}

\section{Zakiyah}

Fakultas Studi Islam, Universitas Islam Kalimantan Muhammad Arsyad al-Banjari, Banjarmasin, Indonesia. E-mail: kikiayoenani@yahoo.com

\section{ARTICLE INFO}

Keywords:

Endorsement; Islamic Business Ethics; Product Sales

\section{Kata Kunci:}

Endorsement; Etika Bisnis Islam; Penjualan Produk

\section{ABSTRACT}

This study aims to determine the cause of the phenomenon of endorsement of a product and to find out how the Islamic view of the endorsement phenomenon in terms of Islamic business ethics. This research uses descriptive qualitative method and literature study. Data collection techniques using observation, questionnaires and documentation. The time used in research in the field for 1 month. The research subjects were 15 lecturers from the Islamic Studies Faculty of the Islamic University of Kalimantan Muhammad Arsyad Al Banjari (UNISKA MAB). It can be concluded that the phenomenon of endorsement of the sale of a product with a percentage level of $66.67 \%$ agreed. Because, the endorsement phenomenon is currently widely used by business people to market their products. Besides that endorsement can also be one of the effective marketing strategies that can be relied upon by business people in this modern era. While the phenomenon of endorsement of the sale of a product in terms of Islamic business ethics with a percentage level of $63.33 \%$ states Neutral. That is, the phenomenon of endorsement in this modern era can not be said to be appropriate and / or not in accordance with Islamic business ethics, because it is still considered to be in the middle.

\section{ABSTRAK}

Penelitian ini bertujuan untuk mengetahui penyebab terjadinya fenomena endorsement terhadap suatu produk dan untuk mengetahui bagaimana pandangan Islam terhadap fenomena endorsement ditinjau dari etika bisnis islam. Penelitian ini menggunakan metode deskriptif kualitatif dan studi literatur. Tekhnik pengumpulan data menggunakan observasi, kuesioner dan dokumentasi. Waktu yang digunakan dalam penelitian di lapangan selama 1 bulan. Subjek penelitian adalah 15 orang Dosen Fakultas Studi Islam Universitas Islam Kalimantan Muhammad Arsyad Al Banjari (UNISKA MAB). Dapat disimpulkan bahwa fenomena endorsement terhadap penjualan suatu produk dengan tingkat persentase sebesar $66,67 \%$ menyatakan Setuju. Karena, fenomena endorsement saat ini telah banyak digunakan oleh pebisnis dalam memasarkan produknya. Selain itu endorsement juga dapat menjadi salah satu strategi pemasaran efektif yang bisa diandalkan oleh 
pebisnis di era modern sekarang ini. Sedangkan fenomena endorsement terhadap penjualan suatu produk ditinjau dari etika bisnis Islam dengan tingkat persentase sebesar 63,33\% menyatakan Netral. Artinya, fenomena endorsement di era modern ini belum bisa dikatakan sudah sesuai dan/atau belum sesuai dengan etika bisnis Islam, karena dianggap masih berada ditengah-tengah.

\section{Pendahuluan}

Perkembangan media sosial pada sekarang ini menjadikan semakin banyak fenomenafenomena baru yang hadir di masyarakat setiap hari. Salah satunya dalam perkembangan ekonomi dunia, strategi pemasaran akhir-akhir ini banyak dilakukan dengan cara Endorsement melalui media instagram. Endorsement merupakan salah satu strategi komunikasi produk untuk menarik peminat secara online.

Endorsement adalah suatu kegiatan promosi yang dilakukan oleh orang-orang yang menjadi selebriti instagram yang telah diminta oleh seorang penjual atau owner suatu produk dan mendapatkan bayaran dengan tarif masing-masing. Kegiatan ini merupakan semacam iklan yang dilakukan oleh para artis pada umumnya, yang kemudian mendapatkan bayaran atas usahanya mempromosikan produk. Hal tersebut bisa dikatakan efektif apabila dianggap mampu mencapai tujuan. Selain itu, keberhasilan kegiatan endorsement biasanya tergantung dengan kecakapan figur untuk membangun citra dari online shop tersebut. Namun, kegiatan endorsement tidak sepenuhnya bisa berjalan sesuai dengan keinginan penjual dikarenakan terkadang para selebriti menjalakan promosi dengan semaunya.

Etika bisnis Islam hadir sebagai cermin atas tindakan-tindakan ekonomi yang selama ini berkembang di masyarakat, khususnya Indonesia. Etika berasal dari bahas Yunani yang diambil dari kata "ethikos" yang berarti "timbul dari kebiasaan". Etika adalah ilmu yang berhubungan denga moral dan berperan menentukan apa yang boleh dilakukan oleh seseorang maupun tidak. “1

Etika bisnis Islam merupakan suatu tindakan untuk mengetahui apa yang benar dan apa yang salah dalam menjalankan suatu usaha atau bisnis dengan perspektif Islam itu sendiri." Bisnis Islam sendiri dimaksudkan agar umat muslim yang menjalakannya dituntut untuk berhati-hati atas adanya unsur keharaman yang timbul baik secara disengaja maupun tidak disengaja.

Endorsement bukanlah suatu kegiatan yang dilarang dalam syariat Islam, kerena termasuk salah satu tindakan komunikasi promosi, tapi kebanyakan pelaku melakukan iklan yang berlebihan ketika mempromosikan suatu produk untuk mendapatkan keuntungan, meski harus menutupi kekurangan dari produk yang diiklankan tersebut sehingga bisa menimbulkan kerugian bagi para konsumen. Oleh karena itu fenomena endorsement ini memiliki sisi positif dan negatif tersendiri, hal ini seperti yang telah dijelaskan oleh Ahmad Ridwan, bahwa etika bisnis Islam memiliki prinsip-prinsip, satu di antaranya adalah, "Janganlah menyembunyikan kecacatan suatu barang". Salah

\footnotetext{
${ }^{1}$ Rafik Issa Beekum, Etika Bisnis Islami (Yogyakarta: Pustaka Pelajar, 2004).
} 
satu penyebab hilangnya keberkahan pada jual beli, jika seseorang menjual barang yang telah cacat, lalu disembunyikannya. Rasulullah saw. Telah bersabda: "Apabila engkau berjual beli, Katakanlah, "tidak ada tipuan". Yang juga termaktub dalam sabda Rasulullah saw. Yang lain, yaitu "Sumpah itu melariskan dagangan, tetapi menghapus keberkahan"(HR. Bukhori)".

Berdasarkan latar belakang tersebut, maka penulis tertarik untuk meneliti tentang Endorsement yang lebih di titik fokuskan pada masalah etika bisnis islam. Secara teoritis-normatif, penelitian ini bertujuan untuk mengetahui penyebab terjadinya fenomena endorsement terhadap suatu produk dan mengetahui bagaimana pandangan Islam terhadap fenomena endorsement ditinjau dari etika bisnis islam. Secara praktis penelitian ini sebagai upaya akademis dan diharapkan dapat bermanfaat bagi siapa saja yang tertarik untuk mengkaji label halal. Selain itu, bagi kalangan akademisi, penelitian ini diharapkan mampu memberikan kontribusi bagi pengembangan pemikiran ilmiah yang skeptis, analitis, dan kritis. Ide-ide dalam penelitian ini tidak terbantahkan.

\section{Kajian Teori}

\section{Pengertian Endorsement}

Endorsement berasal dari kata endorse. Jika diterjemahkan secara sempit, arti endorsement yaitu mendukung atau memberi nasihat. Pengertian endosemen di bank berarti memberikan kuasa, dalam hal ini berupa pemindahan hak kepada orang lain atas surat berharga yang dapat dipindahtangankan. Misalnya pengesahan cek dan wesel dengan membubuhkan nama dan tanda tangan pengesahan pada halaman belakang surat berharga. pengertian endosemen dalam asuransi adalah lampiran perubahan polis, yang dapat memperluas pertanggungan atau bahkan mempersempit pertanggungan. Endorsement yang banyak digunakan saat ini adalah celebrity endorsement.

Yang dimaksud dengan endorsement selebriti adalah mendukung artis untuk menggunakan produk tertentu dan artis tersebut dibayar dan terikat kontrak untuk menjadi duta produk dan tidak boleh terlibat dalam iklan lain dalam produk serupa untuk jangka waktu tertentu. Ada juga yang disebut dukungan media sosial. Endorsement yang marak di jejaring sosial saat ini sangat jauh berbeda dengan pengertian di atas.

Endorsement kini menjadi bentuk kerjasama antara kedua belah pihak yang saling menguntungkan. Dalam hal ini antara toko online dan artis. Endorse adalah cara promosi di akun Twitter atau Instagram dengan memberikan merchandise gratis kepada artis untuk dipromosikan di akun Twitter atau Instagram mereka. Produk gratis yang diberikan sebelumnya akan digunakan oleh artis, difoto dan kemudian diposting di akun Twitter atau Instagram miliknya. Jangan lupa sebutkan nama toko online yang di endorse.

Manfaat endorsement ini bagi kedua belah pihak bagi online shop atau produsen produk tertentu tentunya dapat meningkatkan volume penjualan, karena produk 
tersebut telah diposting dengan kalimat dukungan oleh artis. Bukan rahasia lagi bahwa apa yang dikenakan artis, para penggemar akan berduyun-duyun ke sana. Dengan demikian, sangat membantu bagi toko online dalam meningkatkan penjualannya.

Endorser menurut Terence A. Shimp (2007) yaitu pendukung iklan atau yang dikenal juga sebagai bintang iklan dalam mendukung iklan atau mempromosikan produknya. Endorser terbagi dalam 2 jenis, yaitu: ${ }^{2}$

a. Typical-Person Endorser adalah orang biasa yang tidak terkenal untuk mengiklankan suatu produk.

b. Celebrity Endorser adalah penggunaan orang terkenal (Public Figure) dalam mendukung suatu iklan.

Kedua tipe endorser di atas memiliki atribut dan karakteristik yang sama namun hanya berbeda dalam penggunaan orang sebagai pendukung, apakah karakter yang digunakan adalah tokoh terkenal atau tidak.

Penggunaan selebriti dipilih terutama dari dunia showbiz dan sangat disukai oleh biro iklan. Pengertian celebrity endorser menurut Shimp (2007) adalah seorang aktor atau artis, entertainer atau atlet yang dikenal atau dikenal publik karena keberhasilannya di bidangnya masing-masing untuk mendukung suatu produk yang diiklankan. Sedangkan Orang Khas Endorser adalah orang biasa yang tidak terkenal dalam mengiklankan suatu produk. Selebriti sering digunakan karena atribut selebriti mereka termasuk kecantikan, keberanian, bakat, keanggunan, kekuatan dan daya tarik seksual yang sering mewakili daya tarik yang diinginkan perusahaan periklanan. Yang membuat selebriti efektif sebagai pendukung produk tertentu dalam sebuah iklan adalah jika ada hubungan atau kecocokan yang berarti antara selebriti dengan produk yang diiklankan. ${ }^{3}$

Atribut (kinerja) endorser menurut Terence A. Shimp (2007) yang diterjemahkan oleh Revyani Sjahrial yaitu: Daya Tarik (Attractiveness), daya tarik tidak hanya berkaitan dengan daya tarik fisik tetapi juga mencakup akhlak mulia yang dirasakan konsumen dalam diri endorser, seperti : kemampuan intelektual, kepribadian, karakteristik, gaya hidup dan keterampilan atletik. Konsep umum daya tarik terdiri dari 3 (tiga) gagasan yang berkaitan dengan kesamaan, keakraban, dan kesukaan. Jadi, seorang endorser dianggap menarik bagi konsumen jika konsumen dapat memberikan rasa kesamaan atau keakraban, dengan catatan jika konsumen memiliki kesamaan. ${ }^{4}$

\footnotetext{
${ }^{2}$ Terence A. Shimp, Periklanan Promosi: Aspek Tambahan Komunikasi Pemasaran Terpadu, Terjemahan (Jakarta: Erlangga, 2007).

${ }^{3}$ A. Shimp.

${ }^{4}$ A. Shimp.
} 


\section{Etika Bisnis dalam Perspektif Islam}

Menurut Webster's Dictionary (2012), etika merupakan ilmu tentang perilaku manusia, prinsip-prinsip sistematis dari tindakan moral yang benar. Perbedaan akhlak dan etika adalah bahwa etika merupakan cabang filsafat yang berangkat dari akal, sedangkan akhlak adalah ilmu yang mengajarkan mana yang baik dan mana yang buruk, berdasarkan ajaran Allah SWT. dan Rasulullah SAW. ${ }^{5}$ Etika memiliki makna yang lebih luas, yaitu: ${ }^{6}$

a. Etika berarti pandangan tentang baik dan buruk.

b. Etika juga berarti ilmu yang mempertimbangkan perbuatan manusia baik atau buruk.

c. Bahkan etika berarti nilai-nilai universal yang baik

Berkenaan dengan nilai-nilai luhur yang terkandung dalam etika Islam dalam kaitannya dengan sifat baik perbuatan atau perlakuan yang patut dan dianjurkan untuk dilakukan sebagai sifat yang terpuji, lebih lanjut Sudarsono menyatakan, antara lain: "Jujur (Al Amanah), berbuat baik. baik kepada kedua orang tua (Birrul Waalidaini), menjaga kesucian diri (Al Iffah), kasih sayang (Ar Rahman dan Al Barry), hemat (Al lqtishad), menerima apa adanya dan sederhana (Qona'ah dan Zuhud), perilaku yang baik (Ihsan), kebenaran (Siddiq), pengampunan ('Afu), keadilan ('Adl), keberanian (Syaja'ah), malu (Haya'), kesabaran (Shabr), syukur, penyantun (Hindun), kasih sayang bersama (Muwastt), kuat (Quwwah)".7 Ada beberapa hal yang termasuk dalam bidang sensitif dalam etika bisnis, yaitu: ${ }^{8}$

a. Kebenaran dan kejujuran dasar

b. Hubungan saling percaya antar mitra bisnis

c. Adil dalam hubungan pelanggan

d. Etika dan tanggung jawab karyawan dalam melaksanakan pekerjaan

e. Bertanggung jawab untuk menggunakan sumber daya dan aset perusahaan

f. Keamanan dan kualitas produk

g. Keselamatan dan kesehatan di tempat kerja

h. Perilaku suap

i. Pelestarian lingkungan

j. Penghematan biaya, tidak ada mark-up dan pemborosan

k. Praktek dalam penjualan, promosi dan pemasaran secara umum

\footnotetext{
${ }^{5}$ Buchari Alma and Donni Juni Priansa, Manajemen Bisnis Syariah (Bandung: CV. Alfabelta, 2016).

${ }^{6}$ Hasan Aedy, Teori Dan Aplikasi Etika Bisnis Islam, 1st ed. (Bandung: CV. Alfabelta, 2011).

${ }^{7}$ Annisa Mardatillah, “Etika Bisnis dalam Perspektif Islam,” JIS Vol. 6 (2013): 89-98.

${ }^{8}$ Alma and Priansa, Manajemen Bisnis Syariah.
} 
Untuk membangun budaya bisnis yang sehat, ideal dan islami, harus sesuai dengan prinsip-prinsip etika bisnis islami sebagai berikut: ${ }^{9}$

a. Konsep Ihsan

Ihsan adalah upaya individu untuk benar-benar bekerja keras tanpa menyerah dengan penuh dedikasi menuju optimalisasi, sehingga memperoleh hasil yang maksimal. ${ }^{10}$

b. Itqan

Artinya melakukan sesuatu dengan hati-hati dan teratur. Jadi harus bisa menjaga kualitas agar hasilnya maksimal, seperti: a) konsep hemat, b) kejujuran dan keadilan, c) kerja keras. ${ }^{11}$

c. Kesatuan Tauhid Unity

Islam menawarkan integrasi antara agama, ekonomi dan sosial untuk membentuk kesatuan. Atas dasar pandangan ini, etika dan bisnis menjadi terintegrasi secara vertikal dan horizontal, membentuk persamaan yang sangat penting dalam sistem Islam.

d. Keseimbangan (Equilibrium/Adil)

Islam sangat menganjurkan untuk berlaku adil dalam bisnis. Selingkuh dalam bisnis adalah tanda kehancuran bisnis. Al-Qur'an memerintahkan umat Islam untuk menimbang dan mengukur dengan cara yang benar dan tidak melakukan penipuan berupa pengurangan takaran dan timbangan.

e. Kehendak Bebas (Free Will)

Kecenderungan manusia untuk terus menerus memenuhi kebutuhan pribadi yang tidak terbatas dikendalikan oleh kewajiban setiap individu kepada masyarakat melalui zakat, infaq dan sedekah.

f. Tanggung Jawab (Responsibility)

Kebebasan tanpa batas merupakan sesuatu yang tidak mungkin dilakukan manusia karena tidak memerlukan akuntabilitas dan akuntabilitas untuk memenuhi tuntutan keadilan dan persatuan, manusia perlu bertanggung jawab secara logika atas perbuatannya. Prinsip ini erat kaitannya dengan kehendak bebas.

g. Kebenaran: Kebajikan dan Kejujuran

Kebenaran dalam konteks ini selain mengandung makna kebenaran sebagai lawan dari kesalahan, juga mengandung dua unsur, yaitu kebajikan dan

\footnotetext{
${ }^{9}$ Nur Dinah Fauziah, Muawanah, and Sundari, Etika Bisnis Syariah, Cet. 2 (Malang: CV. Literasi Nusantara Abadi, 2019).

${ }_{10}$ Veithzal Rivai Zainal et al., Islamic Entrepreneurship: Maju, Berkembang Dan Bertahan Dengan Teladan Bisnis Rasulullah, 1st ed. (Yogyakarta: BPFE, 2017).

${ }^{11}$ Zainal et al.
} 
kejujuran. Dalam konteks bisnis, kebenaran diartikan sebagai niat, sikap dan perilaku yang benar, sikap dan perilaku yang benar yang meliputi proses kontrak (transaksi), proses mencari atau memperoleh komoditas pembangunan serta dalam proses mencapai atau menentukan keuntungan. . Dengan prinsip kebenaran ini, etika bisnis Islam benar-benar menjaga dan mencegah kemungkinan kerugian salah satu pihak yang melakukan transaksi, kerjasama atau kesepakatan dalam bisnis. ${ }^{12}$

\section{Etika Bisnis Islam dalam Kegiatan Endorsement}

Sebagai konsumen yang bijak tentu saja akan memiliki banyak pertimbangan dalam pembelian suatu barang atau penggunaan jasa yang ditawarkan oleh celebrity endorsement, konsumen yang memiliki selektivitas tinggi tentu akan memperhatikan apkes-aspek lain selain dari segi kualitas, di antaranya merek, kehalalan, kandungan bahan, dan juga kelayakan dari sebuah produk. Karena itulah etika bisnis Islam hadir untuk mengatur tindakan secara halal dalam segala aspek bisnis.

Seorang selebriti instagram muslim yang baik haruslah memiliki pertimbangan dan kepahaman atas apa yang benar untuk dilakukan dan apa yang tidak dibenarkan dalam syari'at. "Selain kehalalan suatu produk yang harus dijalankan oleh pihak produsen, proses pemasaran dan penghasilan pun juga harus diperhatikan kehalalannya, seperti yang diatur dalam RUU tentang jaminan produk halal yang terdiri dari makanan dan minuman, pakaian, kosmetik, produk obat-obatan, dan lain-lain."13

Penjelasan mengenai jaminan kehalalan untuk penggunaan suatu produk terdapat pada Qs. Al-Baqarah ayat 168:

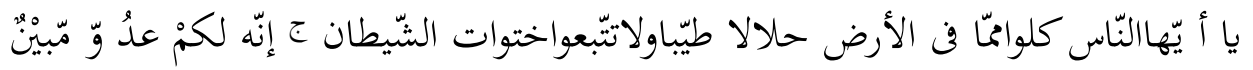

Artinya: "Hai sekalian manusia, makanlah yang halal lagi baik dari apa yang terdapat di bumi, dan janganlah kamu mengikuti langkah-langkah setan; karena sesungguhnya setan itu adalah musuh yang nyata bagimu."

Dari ayat tersebut, sudah jelas dikatakan bahwa Islam tidak melarang memakan apapun selagi itu halal lagi baik dan melarang memakan atau melakukan hal yang tidak jelas kehalalannya, apalagi sampai menimbulkan keharaman. Makanan yang dimaksud bukan hanya sebatas makanan, namun juga segala apa yang menjadi bahan konsumsi, seperti pakaian, kosmetik, dan lain-lain. Sehingga untuk menjalakan kegiatan produksi sebaiknya harus sesuai dengan etika bisnis yang diatur dalam Islam, contohnya bisa melakukan alternatif dengan strategi Islamic Branding. Patut diketahui bahwa "Islamic Branding sudah menjadi trend sejak tahun 2013 meski masih terbilang sebagai konsep yang relatif baru. Konsep ini

\footnotetext{
${ }^{12}$ Abdul Aziz, Etika Bisnis Perspektif Islam (Bandung: Alfabeta, 2013).

${ }^{13}$ Yuliar Rif'adah, "Pengaruh Islamic Endorsement Dan Islamic Branding Terhadap Minat Beli Di Media Sosial Instagram Safi Indonesia" (Surabaya, UIN Sunan Ampel, 2019).
} 
menetapkan nilai-nilai syariah dalam pelaksanaannya termasuk pelaksanaan promosi". ${ }^{14}$ Para pelaku promosi tidak harus melakukan penawaran palsu, atau yang biasa kita sebut dengan jual beli najasy dalam ekonomi syariah. Yang disebut penawaran palsu dalam konteks ini adalah saat para selebriti instagram menarik minat pelanggan dengan janji-janji palsu agar produk tersebut laku di pasaran.

Syariah marketing dalam etika bisnis Islam merupakan sistem pemasaran yang fleksibel dan bisa menjangkau kalangan secara luas. Syariah marketing bukanlah konsep yang anti modernitas, maupun kaku dan fanatis. Allah SWT. Sengaja memberikan kelonggaran ( $a l-' a f w$ ) agar penerapannya senantiasa realistis (alwaqiyyah) dan mampu mengikuti perkembangan jaman. Seperti yang termaktub dalam hadits: "Sesungguhnya Allah telah menciptakan ketentuan-Nya, janganlan kalian langgar. Dia telah menetapkan beberapa perkara yang wajib, janganlah kalian sia-siakan. Dan Dia telah membiarkan dengan sengaja beberapa perkara sebagi bentuk kasih-Nya terhadap kalian, jangan kalian permasalahkan." (HR. AlDaruquthni). ${ }^{15}$

\section{Tinjauan Pustaka}

Pada bagian ini penulis akan memaparkan penjelasan dari penelitian sebelumnya yang kemudian dijadikan sebagai bahan referensi dan referensi dalam melakukan penelitian ini. Belum ada penelitian yang mengkaji masalah "Fenomena Pengesahan Penjualan Produk Ditinjau dari Etika Bisnis Islami". Penelitian-penelitian yang berkaitan dengan permasalahan ini yaitu:

Penelitian Arifin (2018) yang berjudul "Endorsement dalam Perspektif Islam", hasil penelitian menunjukkan bahwa 1). Konsep endorsement dalam perspektif Islam adalah sebagai berikut: Prinsip-prinsip endorsement Islam: a). Siddiq (benar dan jujur). B). Amanah (terpercaya, kredibel). C). Fathanah (cerdas). D). Tabligh (komunikatif)., Ciri-ciri syahadat Islami: a). Ketuhanan (Rabbaniyah), b). Etika (Akhlaqiyyah), c). Realistis (Al-Waqi 'iyyah), d). Humanistik (Al-Insaniyyah). 2). Etika endorse dalam perspektif Islam adalah: a). Barang atau produk yang disahkan harus halal, b). Barang atau produk yang diendorse adalah produk asli, c). Seorang endorser harus ramah dalam melakukan promosi, d). Proses endorsement dilakukan secara santun, e). Tidak ada konten yang mendiskreditkan produk lain, f). Tidak memuji produk yang dipromosikan secara berlebihan, g). Tidak menggunakan kata-kata makian (Demi Allah), h). Transparan dalam mempromosikan suatu produk, i). Endorser harus menutup aurat. ${ }^{16}$

\footnotetext{
14 Dwi Wahyu Pril Ranto, "Menciptakan Islamic Branding sebagai Strategi Menarik Minat Beli Konsumen," no. 2 (2013): 11.

${ }^{15}$ Rif'adah, "Pengaruh Islamic Endorsement Dan Islamic Branding Terhadap Minat Beli Di Media Sosial Instagram Safi Indonesia."

${ }^{16}$ Mahmudi Bin Syamsul Arifin, "Endorsement Dalam Perspektif Islam" (Surabaya, UIN Sunan Ampel, 2018).
} 
Adapun penelitian Rosida, dkk. (2019) yang berjudul "Tinjauan Etika Bisnis Islam terhadap Etika Endorser dalam Praktik Endorsement di Media Sosial Instagram (Studi Kasus pada Nurul Fatimah)", hasil penelitian menunjukkan bahwa: pertama, etika bisnis endorsement dalam Islam adalah barang yang di endorse harus halal dan asli, endorser harus ramah, proses endorsement dilakukan dengan sopan dan santun, endorser harus menutup aurat, tidak memuji berlebihan, melakukan tidak menggunakan kata-kata makian, transparan, tidak menjelekkan produk lain, kedua, praktik endorsement oleh Nurul Fatimah termasuk dalam bai najasy karena telah memenuhi prinsip-prinsip dalam subjek jual beli najasy, dan ketiga, tinjauan etika bisnis Islami. atas praktik endorsement yang dilakukan oleh Nurul Fatimah yang menemukan beberapa etika yang dilanggar. ${ }^{17}$

Lebih lanjut penelitian Farikha (2016) yang berjudul "Strategi Pemasaran Melalui Instagram dengan Sistem Endorsement Ditinjau dari Etika Bisnis Islam (Studi Kasus Di Online Shop Maryam Project)", hasil dari penelitian ini adalah: (1) Strategi pemasaran toko online Maryam Project menggunakan dua jenis endorser yaitu jenis testimonial adalah karakter yang berasal dari orang biasa yang dianggap netral untuk menyampaikan keunggulan produk, dan jenis endorser accesivist adalah penggunaan karakter yang unik dalam bidang tertentu. . (2) Etika bisnis Islami yang terkandung dalam endorsement system yaitu, prinsip kejujuran berupa barang yang sesuai seperti gambar yang tertera di Instagram Maryam Project, dasar etika bisnis Islami, yaitu dasar tanggung jawab yang dilakukan oleh Selebriti Instagram yang langsung memasarkan produk sesuai kesepakatan di akun tersebut. instagram pribadinya. serta menekankan niat baik dan status yang jelas dalam menjalankan usahanya berupa status halal. ${ }^{18}$

\section{Metode Penelitian}

Penelitian ini bertempat di Universitas Islam Kalimantan UNISKA Banjarmasin Kota Banjarmasin dengan subjek penelitian adalah Dosen Fakultas Agama Islam Universitas Islam Kalimantan Muhammad Arsyad Al Banjari (UNISKA MAB).

Jenis penelitian ini merupakan penelitian kualitatif deskriptif. Yang mana penelitian deskriptif merupakan penelitian yang berusaha mendeskripsikan pemecahan masalah yang ada berdasarkan data, menganalisis dan menginterpretasikannya. ${ }^{19}$ Sedangkan kualitatif merupakan metode penelitian yang menekankan pada pendalaman data guna memperoleh kualitas hasil suatu penelitian. ${ }^{20}$

\footnotetext{
${ }^{17}$ Aisyah Puteri Rosadi, Asep Ramdan Hidayat, and Muhammad Yunus, "Tinjauan Etika Bisnis Islam terhadap Etika Endorser dalam Praktik Endorsement di Media Sosial Instagram," Prosiding Hukum Ekonomi Syariah 0, no. 0 (August 1, 2019): 290-97.

${ }^{18}$ Ela Alvianita Farikha, "Strategi Pemasaran Melalui Instagram Dengan Sistem Endorsement Ditinjau Dari Etika Bisnis Islam (Studi Kasus Di Online Shop Maryam Project)” (Kediri, IAIN Kediri, 2016).

${ }^{19}$ Cholid Narbuko and Abu Achmadi, Metodologi Penelitian (Jakarta: PT. Bumi Aksara, 2007).

${ }^{20}$ Ibrahim, Metode Penelitian Kualitatif (Bandung: Alfabeta, 2015).
} 
Teknik pengumpulan data yang digunakan yaitu observasi, angket dan dokumentasi. Sedangkan waktu yang digunakan dalam penelitian di lapangan selama 1 bulan. Setelah data terkumpul, langkah selanjutnya yang dilakukan dengan menganalisis data. Kemudian analisis data disajikan dalam deskripsi.

\section{HASIL DAN PEMBAHASAN}

Berdasarkan hasil penelitian yang telah dilakukan pada Dosen Fakultas Agama Islam Universitas Islam Kalimantan Muhammad Arsyad Al Banjari (UNISKA MAB) Banjarmasin, dapat diuraikan sebagai berikut:

\section{Gambar 1. Data Responden Berdasarkan Jenis Kelamin}

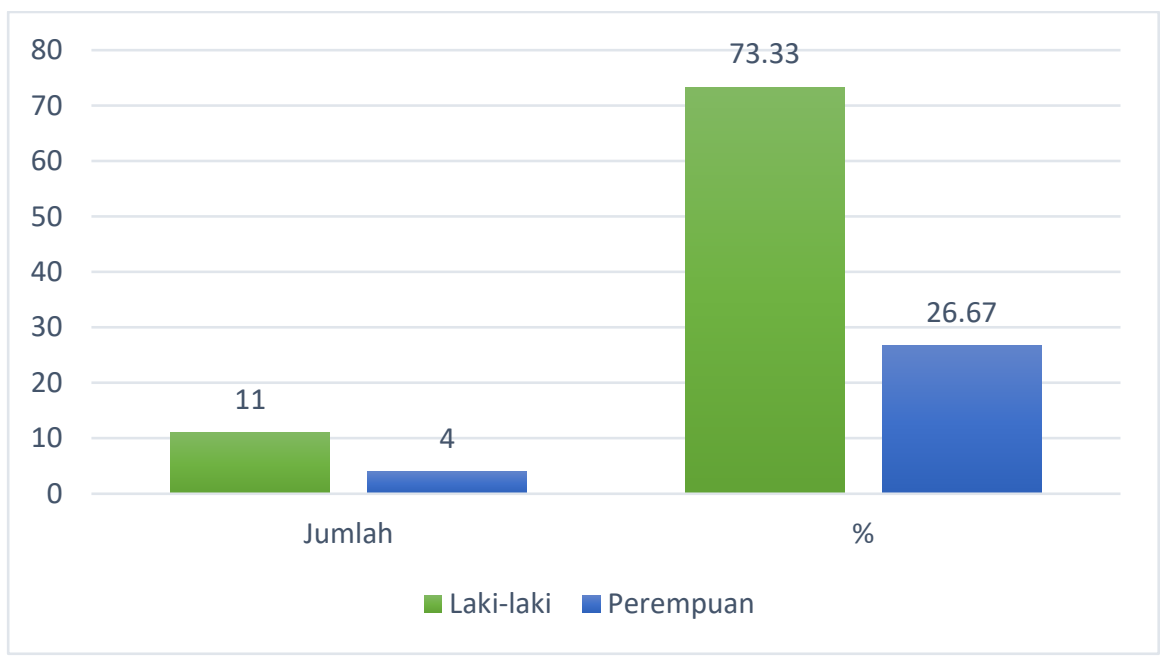

Sumber: Diolah Penulis, 2021.

Pada gambar. 1, menunjukan data responden berdasarkan jenis kelamin. Berdasarkan data di atas, dapat dilihat bahwa responden dalam penenlitian ini lebih dominan berjenis kelamin laki-laki yaitu sebanyak 11 orang $(73,33 \%)$, sedangkan perempuan yaitu sebanyak 4 orang $(26,67 \%)$.

\section{Gambar 2. Data Responden Berdasarkan Usia}

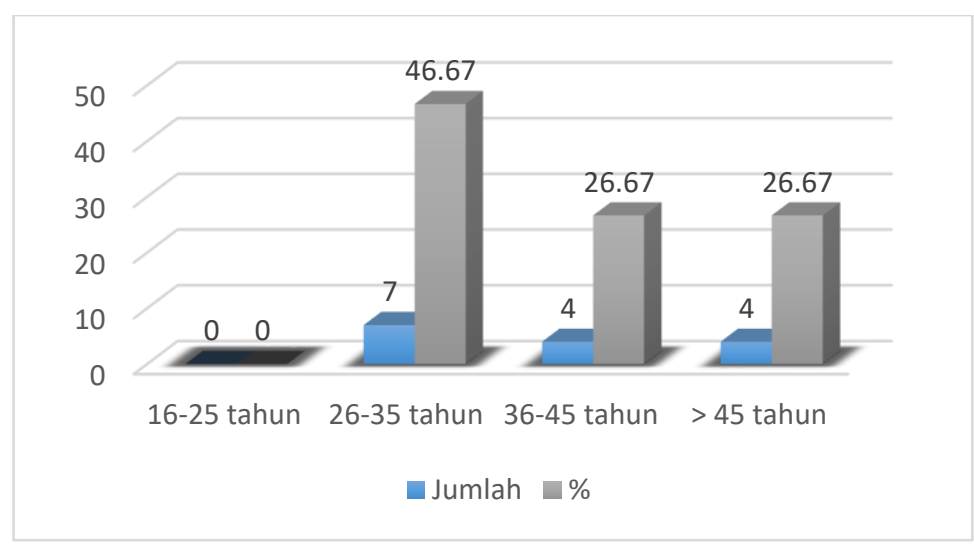

Sumber: Diolah Penulis, 2021. 
Pada gambar. 2, menunjukan data responden berdasarkan usia. Berdasarkan data di atas, dapat dilihat bahwa responden dalam penenlitian ini lebih dominan berusia 2635 tahun yaitu sebanyak 7 orang atau $46.67 \%$. Kemudian diikuti dengan responden yang berusia 36-45 tahun dan lebih dari 45 tahun memiliki kesamaan yaitu masingmasing sebanyak 2 orang atau 26,67\%. Sedangkan responden yang berusia 16-25 tahun yaitu sebanyak 0 orang $(0 \%)$ atau tidak ada dalam penelitian ini.

\section{Gambar 3. Data Responden berdasarkan Pendapatan Perbulan}

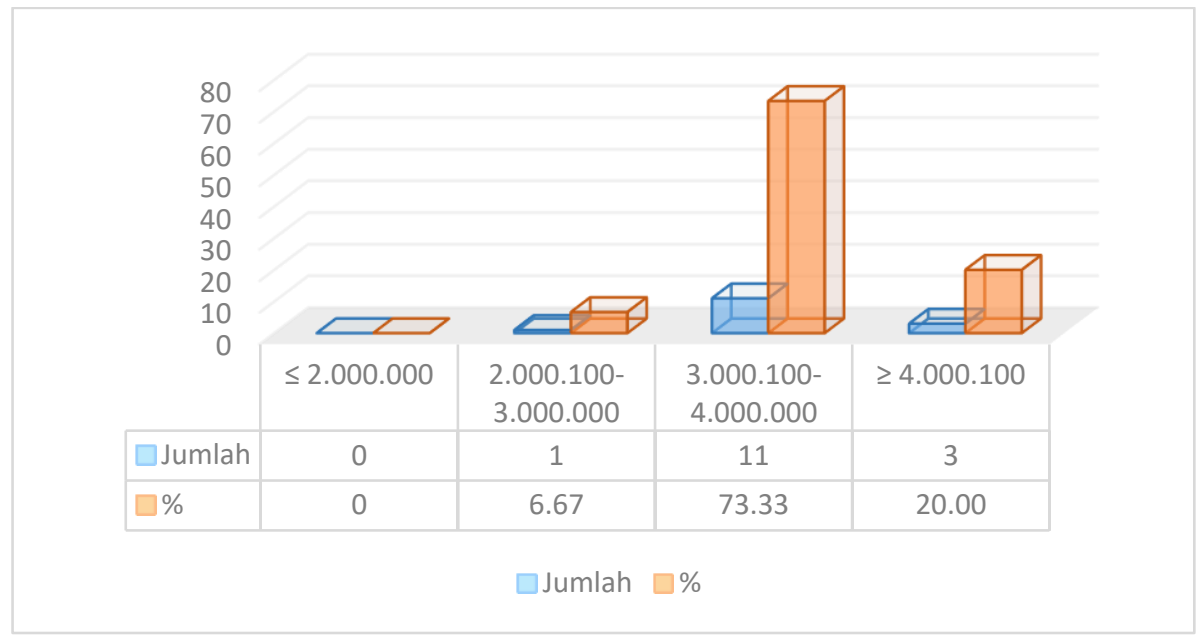

Sumber: Diolah Penulis, 2021.

Pada gambar. 3, menunjukan data responden berdasarkan pendapatan perbulan. Berdasarkan data di atas, dapat dilihat bahwa responden yang memiliki pendapatan kurang dari Rp2.000.000,- perbulan sebanyak 0 orang (0\%) atau tidak ada yang menjadi responden dalam penelitian ini. Sedangkan yang memiliki pendapatan Rp2.000.100,- s/d Rp3.000.000,- perbulan merupakan responden terbanyak ketiga yaitu sebanyak 1 orang (6.67\%). Selanjutnya responden yang memiliki pendapatan Rp3.000.100,- s/d Rp4.000.000,- perbulan merupakan responden terbanyak yaitu 11 orang (73,33\%). Kemudian responden yang memiliki pendapatan lebih dari Rp4.000.000,- perbulan sebagai terbanyak kedua yaitu 3 orang (20\%).

Gambar 4. Data Responden Berdasrkan Memperoleh Informasi Produk

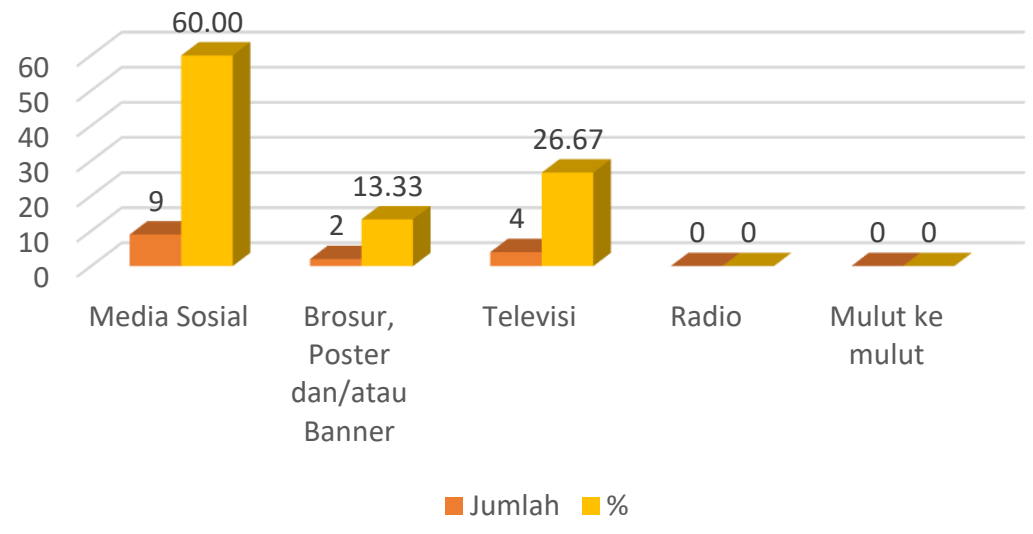

Sumber: Diolah Penulis, 2021. 
Pada gambar. 4, menampilkan data responden berdasarkan perolehan informasi produk. Berdasarkan data di atas terlihat bahwa responden yang menerima informasi melalui iklan di media sosial paling dominan yaitu 9 orang (60\%). Sedangkan yang memperoleh informasi melalui brosur, poster dan/atau banner merupakan terbanyak ketiga yaitu sebanyak 2 orang $(13,33)$. Selanjutnya responden yang memperoleh informasi dari televisi merupakan terbanyak kedua yaitu sebanyak 4 orang (26.67\%). Kemudian yang memperoleh informasi melalui radio memiliki angka yang sama dengan informasi mulut ke mulut yaitu sebanyak 0 orang $(0 \%)$ atau tidak ada responden dalam penelitian ini.

Hasil penelitian yang telah dilakukan mengenai tanggapan responden terhadap fenomena endorsement oleh Dosen Fakultas Agama Islam Universitas Islam Kalimantan Muhammad Arsyad Al Banjari (UNISKA MAB) Banjarmasin pada penjualan suatu produk dapat dideskripsikan sebagai berikut.

Tabel 1. Tanggapan Responden Terhadap Fenomena Endorsement

\begin{tabular}{|c|c|c|c|c|c|c|c|}
\hline No & Pernyataan & STS & TS & $\mathbf{N}$ & $S$ & SS & Jlh \\
\hline 1 & $\begin{array}{l}\text { Dengan adanya endorsement } \\
\text { bisa menarik minat pembeli }\end{array}$ & 1 & 1 & 1 & 11 & 1 & 15 \\
\hline 2 & $\begin{array}{l}\text { Saya setuju dengan adanya } \\
\text { endorsement sebagai promosi } \\
\text { produk }\end{array}$ & 1 & 1 & 1 & 12 & 0 & 15 \\
\hline 3 & $\begin{array}{l}\text { Dengan adanya endorsement } \\
\text { calon pembeli sangat terbantu } \\
\text { untuk membuat keputusan } \\
\text { dalam pembelian }\end{array}$ & 1 & 1 & 4 & 9 & 0 & 15 \\
\hline 4 & $\begin{array}{l}\text { Dengan adanya endorsement } \\
\text { barang apa saja bisa laku } \\
\text { dipasaran }\end{array}$ & 1 & 4 & 1 & 8 & 1 & 15 \\
\hline 5 & $\begin{array}{lr}\text { Saya merasa } & \text { peran } \\
\text { endorsement } & \text { sangat } \\
\text { menguntungkan bagi } & \text { pemilik } \\
\text { produk } & \end{array}$ & 1 & 1 & 1 & 11 & 1 & 15 \\
\hline 6 & $\begin{array}{l}\text { Jika saya pengusaha, maka saya } \\
\text { tertarik menggunakan jasa } \\
\text { endorsement untuk } \\
\text { mempromosikan }\end{array}$ & 1 & 3 & 1 & 9 & 1 & 15 \\
\hline & Total & 6 & 11 & 9 & 60 & 4 & 90 \\
\hline & $\begin{array}{l}\text { gkat Pernyataan = total } / \text { jumlah } \\
\text { indikator pertanyaan }\end{array}$ & 1.00 & 1.83 & 1.50 & 10.00 & 0.67 & 15 \\
\hline & $\begin{array}{l}\text { Tingkat Pernyataan terhadap } \\
\text { enomena Endorsement dalam } \\
\text { persentase (\%) }\end{array}$ & $6.67 \%$ & $12.22 \%$ & $10.00 \%$ & $66.67 \%$ & $4.44 \%$ & $100 \%$ \\
\hline
\end{tabular}


Rumus: tingkat pernyataan / jumlah

responden $\times 100$

Sumber: Diolah Penulis, 2021.

Pada tabel.1 di atas, menunjukan tanggapan responden terhadap pernyataan fenomena endorsement terhadap penjualan suatu produk. Berdasarkan data pada tabel tersebut, dapat dijelaskan bahwa pernyataan dengan adanya endorsement bisa menarik minat pembeli yang menyatakan Sangat Tidak Setuju yaitu sebanyak 1 orang (6,67\%), yang menyatakan Tidak Setuju yaitu sebanyak 1 orang $(6,67 \%)$, yang menyatakan Netral yaitu sebanyak 1 orang (6,67\%), yang menyatakan Setuju merupakan yang paling dominan yaitu sebanyak 11 orang $(73,33 \%)$, dan yang menyatakan Sangat Setuju yaitu sebanyak 1 orang $(6,67 \%)$. Sedangkan pernyataan Saya setuju dengan adanya endorsement sebagai promosi produk yang menyatakan Sangat Tidak Setuju yaitu sebanyak 1 orang $(6,67 \%)$, yang menyatakan Tidak Setuju yaitu sebanyak 1 orang $(6,67 \%)$, yang menyatakan Netral yaitu sebanyak 1 orang (6,67\%), yang menyatakan Setuju merupakan yang paling dominan yaitu sebanyak 12 orang $(80 \%)$, dan yang menyatakan Sangat Setuju yaitu sebanyak 0 orang $(0 \%)$. Kemudian pernyataan dengan adanya endorsement calon pembeli sangat terbantu untuk membuat keputusan dalam pembelian yang menyatakan Sangat Tidak Setuju yaitu sebanyak 1 orang $(6,67 \%)$, yang menyatakan Tidak Setuju yaitu sebanyak 1 orang $(6,67 \%)$, yang menyatakan Netral yaitu sebanyak 4 orang $(26,67 \%)$, yang menyatakan Setuju merupakan yang paling dominan yaitu sebanyak 9 orang $(60 \%)$, dan yang menyatakan Sangat Setuju yaitu sebanyak 0 orang (0\%). Selanjutnya pernyataan dengan adanya endorsement barang apa saja bisa laku dipasaran yang menyatakan Sangat Tidak Setuju yaitu sebanyak 1 orang (6,67\%), yang menyatakan Tidak Setuju yaitu sebanyak 4 orang (26,67\%), yang menyatakan Netral yaitu sebanyak 1 orang (6,67\%), yang menyatakan Setuju merupakan yang paling dominan yaitu sebanyak 8 orang (53,33\%), dan yang menyatakan Sangat Setuju yaitu sebanyak 1 orang $(6,67 \%)$. Lebih lanjut pernyataan Saya merasa peran endorsement sangat menguntungkan bagi pemilik produk yang menyatakan Sangat Tidak Setuju yaitu sebanyak 1 orang $(6,67 \%)$, yang menyatakan Tidak Setuju yaitu sebanyak 1 orang $(6,67 \%)$, yang menyatakan Netral yaitu sebanyak 1 orang (6,67\%), yang menyatakan Setuju merupakan yang paling dominan yaitu sebanyak 11 orang $(73,33 \%)$, dan yang menyatakan Sangat Setuju yaitu sebanyak 1 orang (6,67\%). Pada pernyataan jika saya pengusaha, maka saya tertarik menggunakan jasa endorsement untuk mempromosikan yang menyatakan Sangat Tidak Setuju yaitu sebanyak 1 orang $(6,67 \%)$, yang menyatakan Tidak Setuju yaitu sebanyak 3 orang (20\%), yang menyatakan Netral yaitu sebanyak 1 orang $(6,67 \%)$, yang menyatakan Setuju merupakan yang paling dominan yaitu sebanyak 9 orang (60\%), dan yang menyatakan Sangat Setuju yaitu sebanyak 1 orang $(6,67 \%)$.

Dari jumlah tersebut, 6 orang dosen Fakultas Studi Islam UNISKA MAB yang memilih sangat tidak setuju (STS) dengan tingkat pernyataan untuk fenomena endorsement suatu produk sebesar 1,00 atau $6,67 \%$ dari total responden. Sedangkan yang memilih tidak setuju (TS) sebanyak 11 dengan tingkat pernyataan untuk fenomena endorsement suatu produk sebesar 1,83 atau $12,22 \%$ dari total responden. Kemudian 


\section{AL-IQTISHADIYAH}

Jurnal Ekonomi Syariah dan Hukum Ekonomi Syariah

yang memilih netral $(\mathrm{N})$ sebanyak 9 dengan tingkat pernyataan untuk fenomena endorsement suatu produk sebesar 1,50 atau $10 \%$ dari jumlah responden. Selanjutnya yang memilih setuju (S) sebanyak 60 dengan tingkat pernyataan untuk fenomena endorsement suatu produk sebesar 10,00 atau $66,67 \%$ dari total responden. Selanjutnya yang memilih sangat setuju (SS) ada 4 dengan tingkat pernyataan untuk fenomena endorsement suatu produk sebesar 0,67 atau 4,44\% dari total responden.

Tabel 2. Tanggapan Responden Terhadap Etika Bisnis Islam

\begin{tabular}{llllllll}
\hline No & \multicolumn{1}{c}{ Pernyataan } & STS & TS & N & S & SS & Jlh \\
\hline 1 & $\begin{array}{l}\text { Endorsement memberikan } \\
\text { informasi yang sesuai dengan fakta } \\
\text { riil produk }\end{array}$ & 0 & 1 & 12 & 1 & 1 & 15 \\
\hline $\begin{array}{l}\text { Endorsement produk sudah } \\
\text { memperhatikan nilai } \\
\text { (menutup aurat) religius }\end{array}$ & 0 & 1 & 13 & 1 & 0 & 15 \\
\hline $3 \quad \begin{array}{l}\text { Endorsement juga sebagai } \\
\text { pengguna riil produk tersebut }\end{array}$ & 0 & 9 & 4 & 1 & 1 & 15 \\
\hline $\begin{array}{l}\text { Endorsement sudah terlihat ada } \\
\text { sikap kebenaran dalam artian } \\
\text { kejujuran terhadap konsumen }\end{array}$ & 0 & 5 & 9 & 0 & 1 & 15 \\
\hline $\begin{array}{l}\text { Endorsement sudah terlihat } \\
\text { bertanggung jawab sesuai dengan } \\
\text { tugasnya masing-masing }\end{array}$ & 0 & 1 & 9 & 5 & 0 & 15 \\
\hline $\begin{array}{l}\text { Saya merasa yakin endorsement } \\
\text { sekarang sudah sesuai dengan etika } \\
\text { bisnis Islam }\end{array}$ & 0 & 1 & 10 & 4 & 0 & 15 \\
\hline Total & 0 & 18 & 57 & 12 & 3 & 90 \\
\hline $\begin{array}{l}\text { Tingkat Pernyataan = total / jumlah } \\
\text { indikator pertanyaan }\end{array}$ & 0.00 & 3.00 & 9.50 & 2.00 & 0.50 & 15 \\
\hline $\begin{array}{l}\text { Bingkat Pernyataan terhadap Etika } \\
\text { Rumus: tingkat pernyataan / jumlah } \\
\text { responden x 100 }\end{array}$ & $0.00 \%$ & $20.00 \%$ & $63.33 \%$ & $13.33 \%$ & $3.33 \%$ & 100 \\
\hline
\end{tabular}

Sumber: Diolah Penulis, 2021

Pada tabel.2 di atas, menunjukan tanggapan responden terhadap pernyataan fenomena endorsement terhadap penjualan suatu produk ditinjau dari etika bisnis Islam. Berdasarkan data pada tabel tersebut, dapat dijelaskan bahwa pernyataan endorsement memberikan informasi yang sesuai dengan fakta riil produk yang menyatakan Sangat Tidak Setuju yaitu sebanyak 0 orang $(0 \%)$, yang menyatakan Tidak Setuju yaitu sebanyak 1 orang (6,67\%), yang menyatakan Netral merupakan yang paling dominan yaitu sebanyak 12 orang $(80 \%)$, yang menyatakan Setuju yaitu 
sebanyak 1 orang $(6,67 \%)$, dan yang menyatakan Sangat Setuju yaitu sebanyak 1 orang (6,67\%). Sedangkan pernyataan endorsement produk sudah memperhatikan nilai religius (menutup aurat) yang menyatakan Sangat Tidak Setuju yaitu sebanyak 0 orang (0\%), yang menyatakan Tidak Setuju yaitu sebanyak 1 orang $(6,67 \%)$, yang menyatakan Netral merupakan yang paling dominan yaitu sebanyak 13 orang $(86,67 \%)$, yang menyatakan Setuju yaitu sebanyak 1 orang $(6,67 \%)$, dan yang menyatakan Sangat Setuju yaitu sebanyak 0 orang $(0 \%)$. Kemudian pernyataan endorsement juga sebagai pengguna riil produk tersebut yang menyatakan Sangat Tidak Setuju yaitu sebanyak 0 orang $(0 \%)$, yang menyatakan Tidak Setuju merupakan yang paling dominan yaitu sebanyak 9 orang $(60 \%)$, yang menyatakan Netral yaitu sebanyak 4 orang (26,67\%), yang menyatakan Setuju yaitu sebanyak 1 orang $(6,67 \%)$, dan yang menyatakan Sangat Setuju yaitu sebanyak 1 orang $(6,67 \%)$. Selanjutnya pernyataan endorsement sudah terlihat ada sikap kebenaran dalam artian kejujuran terhadap konsumen yang menyatakan Sangat Tidak Setuju yaitu sebanyak 0 orang (0\%), yang menyatakan Tidak Setuju yaitu sebanyak 5 orang $(33,33 \%)$, yang menyatakan Netral merupakan yang paling dominan yaitu sebanyak 9 orang (60\%), yang menyatakan Setuju yaitu sebanyak 0 orang $(0 \%)$, dan yang menyatakan Sangat Setuju yaitu sebanyak 1 orang $(6,67 \%)$. Lebih lanjut pernyataan endorsement sudah terlihat bertanggung jawab sesuai dengan tugasnya masing-masing yang menyatakan Sangat Tidak Setuju yaitu sebanyak 0 orang (0\%), yang menyatakan Tidak Setuju yaitu sebanyak 1 orang $(6,67 \%)$, yang menyatakan Netral merupakan yang paling dominan yaitu sebanyak 9 orang (60\%), yang menyatakan Setuju yaitu sebanyak 5 orang $(33,33 \%)$, dan yang menyatakan Sangat Setuju yaitu sebanyak 0 orang (0\%). Pada pernyataan Saya merasa yakin endorsement sekarang sudah sesuai dengan etika bisnis Islam yang menyatakan Sangat Tidak Setuju yaitu sebanyak 0 orang (0\%), yang menyatakan Tidak Setuju yaitu sebanyak 1 orang $(6,67 \%)$, yang menyatakan Netral merupakan yang paling dominan yaitu sebanyak 10 orang $(66,67 \%)$, yang menyatakan Setuju yaitu sebanyak 4 orang $(26,67 \%)$, dan yang menyatakan Sangat Setuju yaitu sebanyak 0 orang (0\%).

Dari total keseluruhan, dosen Fakultas Studi Islam UNISKA MAB yang memilih sangat tidak setuju (STS) sebanyak 0 dengan tingkat pernyataan untuk pernyataan fenomena endorsement terhadap penjualan suatu produk ditinjau dari etika bisnis Islam sebesar 0 atau $0 \%$ dari jumlah responden. Sedangkan yang memilih tidak setuju (TS) sebanyak 18 dengan tingkat pernyataan untuk fenomena endorsement terhadap penjualan suatu produk ditinjau dari etika bisnis Islam sebesar 3,00 atau 20,00\% dari jumlah responden. Kemudian yang memilih netral (N) sebanyak 57 dengan tingkat pernyataan untuk fenomena endorsement terhadap penjualan suatu produk ditinjau dari etika bisnis Islam sebesar 9,50 atau 63,33\% dari jumlah responden. Selanjutnya yang memilih setuju (S) sebanyak 12 dengan tingkat pernyataan untuk fenomena endorsement terhadap penjualan suatu produk ditinjau dari etika bisnis Islam sebesar 2.00 atau $13,33 \%$ dari jumlah responden. Lebih lanjut yang memilih sangat setuju (SS) sebanyak 3 dengan tingkat pernyataan untuk fenomena endorsement terhadap penjualan suatu produk ditinjau dari etika bisnis Islam sebesar 0.50 atau 3,33\% dari jumlah responden. 
Dari hasil analisis di atas maka dapat diambil kesimpulan bahwa pernyataan dosen Fakultas Studi Islam Universitas Islam Kalimantan Muhammad Arsyad Al Banjari (MAB) Banjarmasin untuk fenomena endorsement terhadap penjualan suatu produk, yaitu: 1) Dengan adanya endorsement bisa menarik minat pembeli, pilihan yang paling dominan dengan tingkat persentase sebesar 73,33\%\% menyatakan Setuju. 2) Saya setuju dengan adanya endorsement sebagai promosi produk, pilihan yang paling dominan dengan tingkat persentase sama yaitu sebesar $80 \%$ menyatakan Setuju. 3) Dengan adanya endorsement calon pembeli sangat terbantu untuk membuat keputusan dalam pembelian, pilihan yang paling dominan dengan dengan tingkat peresentase sebesar 60\% menyatakan Setuju. 4) Dengan adanya endorsement barang apa saja bisa laku dipasaran, pilihan yang paling dominan dengan tingkat persentase sebesar 53,33\% menyatakan Setuju. 5) Saya merasa peran endorsement sangat menguntungkan bagi pemilik produk, pilihan yang paling dominan dengan tingkat persentase paling dominan sebesar $73,33 \%$ menyatakan Setuju. 6) Jika saya pengusaha, maka saya tertarik menggunakan jasa endorsement untuk mempromosikan, pilihan yang paling dominan dengan tingkat persentase sebesar $60 \%$ menyatakan Setuju. Dari total keseluruhan atau secara umum tanggapan dosen Fakultas Studi Islam Universitas Islam Kalimantan Muhammad Arsyad Al Banjari (MAB) Banjarmasin terkait fenomena endorsement terhadap penjualan suatu produk dengan tingkat persentase sebesar 66,67\% menyatakan Setuju. Hasil penelitian ini didukung oleh Robbiatul Addawiyah (2019) yang menyakan bahwa berdasarkan sudut pandang pemilik bisnis, celebrity endorsement menjadi strategi pemasaran andalannya karena dapat menaikkan jumlah followersnya di Instagram serta meningkatkan angka penjualan. Sedangkan dari sudut pandang konsumen, celebrity endorsement merupakan hal yang biasa dilakukan dalam upaya promosi. Dengan adanya celebrity endorsement, konsumen mendapatkan beragam referensi produk dari selebgram yang sebelumnya tidak mereka ketahui. ${ }^{21}$ Selain itu, menurut Novy Adityasari mengatakan bahwa salah satu trend pemasaran modern yang ramai saat ini adalah Endorsement, pada sosial media Instagram, fenomena endorsement saat ini telah banyak digunakan oleh pebisnis untuk memasarkan produknya. Karena endorsement dapat menjadi salah satu strategi pemasaran yang efektif yang dapat diandalkan oleh pebisnis di era modern ini. ${ }^{22}$

Sedangkan tanggapan dosen Fakultas Studi Islam Universitas Islam Kalimantan Muhammad Arsyad Al Banjari (MAB) Banjarmasin untuk fenomena endorsement terhadap penjualan suatu produk ditinjau dari etika bisnis Islam, yaitu: 1) Endorsement memberikan informasi yang sesuai dengan fakta riil produk, pilihan yang paling dominan dengan tingkat persentase sebesar $80 \%$ menyatakan Netral. 2) Endorsement produk sudah memperhatikan nilai religius (menutup aurat), pilihan yang paling

\footnotetext{
${ }^{21}$ Robbiatul Addawiyah, "Analisis Penggunaan Celebrity Endorsement Pada Media Sosial Instagram Dalam Tinjauan Ekonomi Islam (Studi Kasus Onlinesshop@blubhandmade)" (Skripsi, Semarang, Universitas Islam Negeri Walisongo, 2019).

${ }^{22}$ Novy Adityasari, “Endorsement Sebagai Trend Media Pemasaran Dalam Perspektif Islam” (Karya Tulis Ilmiah, Universitas Airlangga, Surabaya, 2015).
} 
dominan dengan tingkat persentase sebesar 86,67\% menyatakan Netral. 3) Endorsement juga sebagai pengguna riil produk tersebut, pilihan yang paling dominan dengan tingkat persentase sebesar 60\% menyatakan Tidak Setuju. 4) Endorsement sudah terlihat ada sikap kebenaran dalam artian kejujuran terhadap konsumen, pilihan yang paling dominan dengan tingkat persentase sebesar $60 \%$ menyatakan Netral. 5) Endorsement sudah terlihat bertanggung jawab sesuai dengan tugasnya masing-masing, pilihan yang paling dominan dengan tingkat persentase sebesar $60 \%$ menyatakan Netral. 6) Saya merasa yakin endorsement sekarang sudah sesuai dengan etika bisnis Islam, pilihan yang paling dominan dengan tingkat persentase sebesar $66,67 \%$ menyatakan Netral. Dari total keseluruhan atau secara umum tanggapan dosen Fakultas Studi Islam Universitas Islam Kalimantan Muhammad Arsyad Al Banjari (MAB) Banjarmasin terkait fenomena endorsement terhadap penjualan suatu produk ditinjau dari etika bisnis Islam dengan tingkat persentase sebesar $63,33 \%$ menyatakan Netral. Hasil penelitian ini didukung oleh Ambaryati Hartati (2019) mengatakan bahwa strategi pemasaran Hayu Olshop menggunakan dua jenis endorser yaitu jenis testimonial adalah karakter yang berasal dari orang biasa yang dianggap netral untuk menyampaikan keunggulan produk, dan jenis endorser accesivist adalah penggunaan karakter yang unik dalam bidang tertentu. Namun dalam kegiatan endorsement di Hayu Olshop masih terdapat penyimpangan dari etika bisnis islami, karena masih ada selebritis yang kurang jujur saat melakukan kegiatan promosi di media sosial. Selebriti tidak jujur dalam memberikan review produk kepada konsumen. ${ }^{23}$ Selain itu, menurut Rabbiatul Addawiyah (2019) dalam sebuah penelitian menyatakan bahwa dalam ekonomi Islam, celebrity endorsement memiliki mekanisme yang mirip dengan bai 'najasy. Namun tidak sepenuhnya endorsement selebriti dapat dikatakan sebagai bai' najasy. Selain itu, endorsement selebriti oleh @blubhandmade menjunjung tinggi kejujuran dan menghindari memuji produk secara berlebihan. Sehingga penulis membuat celebrity endorsement menjadi dua kategori, yaitu celebrity endorsement yang wajar dan celebrity endorsement yang cenderung bai' najasy. Dukungan selebriti yang wajar adalah ketika seorang pelaku bisnis meminta seorang selebriti untuk mempromosikan produk mereka dengan menyatakan kemampuan dan kualitas produk yang sebenarnya tanpa melebih-lebihkan dan konsumen tahu bahwa itu hanya promosi. Sementara itu, celebrity endorsement cenderung bai' najasy, yaitu ketika para pelaku bisnis meminta selebriti untuk mempromosikan produknya dengan mengatakan pujian bahkan melebih-lebihkan sehingga calon konsumen ditipu untuk membeli untuk membuktikan kebenaran perkataan selebriti tersebut. ${ }^{24}$

Sehingga, dapat disimpulkan bahwa fenomena endorsement terhadap penjualan suatu produk dengan tingkat persentase sebesar $66,67 \%$ menyatakan Setuju. Karena, fenomena endorsement saat ini telah banyak digunakan oleh pebisnis untuk memasarkan produknya. Selain itu endorsement juga dapat menjadi salah satu

\footnotetext{
${ }^{23}$ Ambaryati Hartati, "Endorsement Sebagai Strategi Pemasaran Di Tinjau Dari Etika Bisnis Islam (Studi Kasus Di Hayu Olshop Metro)” (Skripsi, Lampung, IAIN metro, 2019).

24 Addawiyah, "Analisis Penggunaan Celebrity Endorsement Pada Media Sosial Instagram Dalam Tinjauan Ekonomi Islam (Studi Kasus Onlinesshop@blubhandmade)."
} 
strategi pemasaran yang efektif yang dapat diandalkan oleh pebisnis di era modern ini. Sedangkan fenomena endorsement terhadap penjualan suatu produk ditinjau dari etika bisnis Islam dengan tingkat persentase sebesar 63,33\% menyatakan Netral. Artinya, fenomena endorsement di era modern ini belum bisa dikatakan sudah sesuai dan/atau belum sesuai dengan etika bisnis Islam, karena dianggap masih berada ditengah-tengah.

\section{Penutup}

Berdasarkan pembahasan sebelumnya, dapat disimpulkan bahwa Fenomena endorsement terhadap penjualan suatu produk dengan tingkat persentase sebesar $66,67 \%$ menyatakan Setuju. Karena, fenomena endorsement saat ini telah banyak digunakan oleh pebisnis untuk memasarkan produknya. Selain itu endorsement juga dapat menjadi salah satu strategi pemasaran yang efektif yang dapat diandalkan oleh pebisnis di era modern ini. Selanjutnya fenomena endorsement terhadap penjualan suatu produk ditinjau dari etika bisnis Islam dengan tingkat persentase sebesar $63,33 \%$ menyatakan Netral. Artinya, fenomena endorsement di era modern ini belum bisa dikatakan sudah sesuai dan/atau belum sesuai dengan etika bisnis Islam, karena dianggap masih berada ditengah-tengah.

\section{DAFTAR PUSTAKA}

A. Shimp, Terence. Periklanan Promosi: Aspek Tambahan Komunikasi Pemasaran Terpadu. Terjemahan. Jakarta: Erlangga, 2007.

Addawiyah, Robbiatul. "Analisis Penggunaan Celebrity Endorsement Pada Media Sosial Instagram Dalam Tinjauan Ekonomi Islam (Studi Kasus Onlinesshop@blubhandmade)." Skripsi, Universitas Islam Negeri Walisongo, 2019.

Adityasari, Novy. "Endorsement Sebagai Trend Media Pemasaran Dalam Perspektif Islam." Karya Tulis Ilmiah. Universitas Airlangga, Surabaya, 2015.

Aedy, Hasan. Teori Dan Aplikasi Etika Bisnis Islam. 1st ed. Bandung: CV. Alfabelta, 2011.

Alma, Buchari, and Donni Juni Priansa. Manajemen Bisnis Syariah. Bandung: CV. Alfabelta, 2016.

Arifin, Mahmudi Bin Syamsul. "Endorsement Dalam Perspektif Islam." UIN Sunan Ampel, 2018.

Aziz, Abdul. Etika Bisnis Perspektif Islam. Bandung: Alfabeta, 2013.

Beekum, Rafik Issa. Etika Bisnis Islami. Yogyakarta: Pustaka Pelajar, 2004.

Farikha, Ela Alvianita. "Strategi Pemasaran Melalui Instagram Dengan Sistem Endorsement Ditinjau Dari Etika Bisnis Islam (Studi Kasus Di Online Shop Maryam Project)." IAIN Kediri, 2016. 
Fauziah, Nur Dinah, Muawanah, and Sundari. Etika Bisnis Syariah. Cet. 2. Malang: CV. Literasi Nusantara Abadi, 2019.

Hartati, Ambaryati. "Endorsement Sebagai Strategi Pemasaran Di Tinjau Dari Etika Bisnis Islam (Studi Kasus Di Hayu Olshop Metro)." Skripsi, IAIN metro, 2019.

Ibrahim. Metode Penelitian Kualitatif. Bandung: Alfabeta, 2015.

Mardatillah, Annisa. "Etika Bisnis dalam Perspektif Islam." JIS Vol. 6 (2013): 89-98.

Narbuko, Cholid, and Abu Achmadi. Metodologi Penelitian. Jakarta: PT. Bumi Aksara, 2007.

Ranto, Dwi Wahyu Pril. “Menciptakan Islamic Branding sebagai Strategi Menarik Minat Beli Konsumen," no. 2 (2013): 11.

Rif'adah, Yuliar. "Pengaruh Islamic Endorsement Dan Islamic Branding Terhadap Minat Beli Di Media Sosial Instagram Safi Indonesia." UIN Sunan Ampel, 2019.

Rosadi, Aisyah Puteri, Asep Ramdan Hidayat, and Muhammad Yunus. "Tinjauan Etika Bisnis Islam terhadap Etika Endorser dalam Praktik Endorsement di Media Sosial Instagram." Prosiding Hukum Ekonomi Syariah 0, no. 0 (August 1, 2019): 290-97.

Zainal, Veithzal Rivai, Halim Alamsyah, Sugiharto, and Muhammad Syafi'i Antonio. Islamic Entrepreneurship: Maju, Berkembang Dan Bertahan Dengan Teladan Bisnis Rasulullah. 1st ed. Yogyakarta: BPFE, 2017. 